\title{
Effect of Learning Achievement of the Eye of Productive Training, Prakerin Experience, and Interests in Student Readiness Entering the World of Work
}

\author{
Dita Nur Faizah \\ Aniek Indrawati \\ Education Administration State University of Malang \\ Email: nurfaizahdita10@gmail.com; aniekindrawati_feum@yahoo.com
}

\begin{abstract}
This study is a quantitative research by using descriptive and ex-post facto. The purpose of this research is to know how: (1) the description of learning achievement, description of internship experience, description of working interest, and description of working readiness; (2) the effect of productive learning achievement, internship experience, and working interest partially on the readiness of work for the students of SMK Negeri 1 Kraksaan Probolinggo. Data collection techniques used are questionnaire and documentation method. The sampling technique used is proportional random sampling. The result of the analysis shows that: (1) student learning achievement of productive, student internship experience, students working interest, and readiness of student work is in good category; (2) there is a negative and not significant influence between learning achievement of productive education and training on job readiness; (3) there is a positive but insignificant influence between internship experience on job readiness; (4) there is a positive but not significant influence between the interest of work to the readiness of class XII business management students in SMK Negeri 1 Kraksaan Probolinggo.
\end{abstract}

Keywords: learning achievement, internship experience, working interest, working readiness

The quality of human resources (HR) is a determinant of the survival of a country. This means that the quality of human resources is also the spearhead for the success of the state. The sign that the country has a good quality of human resources is the lack of unemployment. In overcoming educational unemployment has a very important role because education must print graduates who are ready to work. Currently, education is increasingly closely related to the business world and industry because the concept compiled by the current education focuses on how as much as possible to print graduates ready to work especially for SMK because in addition to providing the theory of SMK also presents industrial work practices or commonly called prakerin. Prakerin is expected to be able to support the students' skills to enter the workforce because this prakerin program has provided experience for students to feel in the working world for a certain period of time.

Yunus (2006: 4) states "Education as an essential factor is even one of the most important elements of a person's life. The level of "education" can be a measure of one's thinking ability level. Talking about education is not easy and simple because, in addition to its complex, dynamic, and contextual nature, education is a vehicle for the formation of one's self as a whole. Thus, education has a role in the formation of self as a human resource (HR) ". Tirtarahardja \& Sulo (2005: 268) states "Vocational education is education that prepares students to be able to work in certain job fields such as engineering, catering, and fashion, hospitality, handicraft, office administration and other educational institutions such as STM, SMTK, SMIP, SMIKA, SMEA ". Basically, vocational education in SMK equips students 
with a set of knowledge, skills, and also attitudes that aims to develop the potential that is in students so that they are better able to enter the workforce (Wena, 1997: $5)$.

In addition to work experience that is owned, the readiness of vocational students is also based on the achievement or mastery of vocational theory, especially the eyes of productive training because with a good mastery of vocational theory makes students more easily understand the situation in the world of work. In other words, learning achievement of productive training and education contribute positively to the readiness of vocational students' work. According to Kuncoro (1996: 4), the productive component equips students to enter the workforce so that the skills possessed previously become professional skills in their field and can make it easier for students to adapt to the work environment.

Job readiness can also be influenced by internal factors of students to prepare for the challenge of entering the workforce. one of the factors within the student is interest. Basically, interest is something that is in someone who is different from one another. Similarly, the interests of students in class XII field of business and management expertise in SMK Negeri 1 Kraksaan Probolinggo. Ideally after having a good learning experience in school, a good prakerin experience from industry, and supported by an interest in work that is in students then it can make students are ready to enter the workforce. This means that the goal of SMK to print graduates who are ready to work can be achieved because in terms of age based on Law No. 13 of 2013 on Employment of vocational students have been eligible to work that is 17 years.

But in fact, based on preliminary observations made at SMK Negeri 1 Kraksaan Probolinggo there are only 35\% of students who work in accordance with their fields. This shows that the three components in the form of learning achievement of productive training and education, prakerin experience and interest in work owned by students cannot guarantee the readiness of students' work in SMK Negeri 1 Kraksaan Probolinggo. This is inversely proportional to some research which states that the three components are a positive and significant influence on students' readiness.

Mu'ayati \& Margunani (2014: 332) stated that there is influence between prakerin, mastery of productive training and work interest to students' readiness. Kurniati \& Subowo (2015: 413) also concluded: "There are significant positive effects of industrial work practices, academic achievement, and work motivation on student work readiness". A similar conclusion is also delivered by Handayani \& Setiyani (2015: 875) "Based on the results of the study can be concluded that the academic achievement of productive workforce accounting training, industrial work practices, and family environment affect the readiness of vocational students".

To be sure the truth, of course, need to be held further research related to the readiness of students in SMK Negeri 1 Kraksaan Probolinggo and to find out how big the contribution of these three components in influencing the readiness of students in SMK Negeri 1 Kraksaaan Probolinggo. Based on the description of the above problems, the researcher wanted to raise the issue into a research entitled "The Effect of Learning Achievement of Productive Training Eye, Prakerin Experience, and Interest in Student Preparedness Entering Working World at SMK Negeri 1 
Kraksaan Probolinggo". Based on the above background, then the hypothesis in this study are as follows:

Ho1: there is a positive and significant effect of learning achievement of productive training on the readiness of work.

Ho2: there is a positive and significant influence of prakerin experience on job readiness.

Ho3: There is a positive and significant influence of work interest on job readiness.

\section{METHOD}

This research was designed with a quantitative approach to knowing the influence of learning achievement of productive training, prakerin, and work interest to work preparedness. The design of this study can be seen in the following figure.

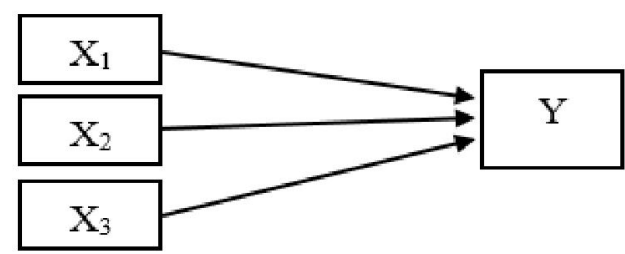

\section{Figure 1. Relationship Model among Variable Research}

Information:

$\mathrm{X} 1 \quad$ : Learning achievement of productive training

X2 : Prakerin Experience

X3 : Interest in work

Y : Readiness work

$\longrightarrow \quad$ : Influence partially

The population in this study is as straight as the class XII students of business and management skills program at SMK Negeri 1 Kraksaan Probolinggo, amounting to 189 students with a sample of 120 respondents with the following calculations.

Table 1. Calculation of Number of Samples

\begin{tabular}{|c|c|c|c|c|}
\hline \multirow[t]{2}{*}{ No } & \multirow[t]{2}{*}{ Class } & \multicolumn{3}{|c|}{ Amount } \\
\hline & & Population & Calculation & Sample \\
\hline 1 & $\begin{array}{l}\text { Class XII PM } \\
1\end{array}$ & 30 student & $30: 189 \times 119=19,8$ & $\begin{array}{c}20 \\
\text { student }\end{array}$ \\
\hline 2 & $\begin{array}{l}\text { Class XII PM } \\
2\end{array}$ & 25 student & $25: 189 \times 119=15,7$ & $\begin{array}{c}20 \\
\text { student }\end{array}$ \\
\hline 3 & $\begin{array}{l}\text { Class XII AK } \\
1\end{array}$ & 34 student & $34: 189 \times 119=21,4$ & $\begin{array}{c}20 \\
\text { student } \\
\text { siswa }\end{array}$ \\
\hline
\end{tabular}




\begin{tabular}{clccc}
\hline 4 & $\begin{array}{l}\text { Class XII AK } \\
2\end{array}$ & 34 student & $34: 189 \times 119=21,4$ & $\begin{array}{c}20 \\
\text { student }\end{array}$ \\
\hline 5 & $\begin{array}{l}\text { Class XII } \\
\text { APK 1 }\end{array}$ & 33 student & $33: 189 \times 119=20,7$ & $\begin{array}{c}20 \\
\text { student } \\
\text { siswa }\end{array}$ \\
\hline 6 & Class XII & 33 student & $33: 189 \times 119=20,7$ & $\begin{array}{c}20 \\
\text { APK 2 }\end{array}$ \\
\hline Amount & $\begin{array}{c}\mathbf{1 8 9} \\
\text { student }\end{array}$ & $\mathbf{1 1 9 , 7}$ (rounded off) $=\mathbf{1 2 0}: \mathbf{6 = 2 0}$ & $\begin{array}{c}\mathbf{1 2 0} \\
\text { student }\end{array}$ \\
\hline
\end{tabular}

Source: Sugiyono, 2015:72

The instrument in this research is questionnaire sheet. Before the instrument used for research must be tested the validity and reliability of the data obtained through a good parameter estimator so that the results are not misleading and can be accounted for. The scale used in the instrument is Likert scale with 5 alternative answers are Strongly Agree / SS debris score 5, Agree / S given score 4, Simply Agree / CS scored 3, Disagree / TS scored 2, and Strongly Disagree / CTS is given a score of 1 . The questionnaire is used to obtain data on the variables of work interest and work readiness, while the learning achievement variables obtained through the value of report cards odd semester 2016/2017 academic year and and for prakerin experience obtained from the final value prakerin students provided by the parties industry.

Sources of data in this study are primary data and secondary data. Primary data obtained from students in the form of answers questionnaires provided by students while the secondary data obtained from teachers productive business management in the form of report cards and final grades prakerin students. Data analysis in this research using descriptive statistical analysis and multiple linear regression. Descriptive statistic analysis is used to describe the achievement of learning of productive training (X1), prakerin (X2) experience, work interest (X3), and student work readiness (Y), while multiple linear regression analysis is used to find out how big influence of independent variable to a variable bound. Prior to double linear regression analysis, there is a prerequisite test that must be done in the form of classical assumption test consisting of three tests in the form of normality test, multicollinearity test, and heteroscedasticity test. Furthermore, the hypothesis test used in this study is the test $\mathrm{f}$. This $\mathrm{f}$ test is needed to find out whether there is a significant positive influence or not between the independent variables to the dependent variable partially to produce two possibilities of the hypothesis accepted or rejected. All the above analysis and test of the researcher do with the help of SPSS program (statistical package for the social sciences). 


\section{DISCUSSION \& RESULT}

\section{Results}

The result of respondent description about the variable of learning achievement of productive training and prakerin experience obtained through documentation method in the good category, this can be proved by $98,80 \%$ student has value report card above KKM, and 89,28\% student has a final value of prakerin start from 80-89. This means that the ability of students in mastering vocational material is very good and work experience that students get through prakerin program is also in the good category. While the results of the description on the variables of work interest and work readiness obtained by the questionnaire method is also in a good category with the result of the average score on the variable of work interest is 4,077 and the job readiness variable is 4,042 . This means that the majority of respondents as many as 120 answered agree and strongly agree on all the revelations submitted.

Based on the results of classical assumption test showed that the data used in this study is normally distributed, there are no multicollinearity symptoms, and there is no heteroscedasticity disorder so it can be stated that the regression equation deserves to be used for the research. Based on the results of multiple linear regression analysis obtained the constant value of 5.557, while the value of the coefficient of learning achievement variable productive training (X1) is -0.036, prakerin experience (X2) of 0.005 , and work interest (X3) of 0.166 . All the results of multiple linear regression analysis are summarized in Table 2 below.

Table 2 Summary of Results of Multiple Linear regression analysis in this study

\begin{tabular}{|c|c|c|c|c|c|}
\hline \multirow{2}{*}{ Model } & \multicolumn{2}{|c|}{ Unstandardized } & \multirow{2}{*}{$\begin{array}{c}\text { Standardized } \\
\text { Coefficients } \\
\text { Beta }\end{array}$} & \multirow[t]{2}{*}{$\mathbf{t}$} & \multirow[t]{2}{*}{ sig } \\
\hline & B & $\begin{array}{l}\text { Std. } \\
\text { Error }\end{array}$ & & & \\
\hline (Constant) & 5.557 & 1.836 & & 3.026 & .003 \\
\hline Learning Achievment $\left(\mathrm{X}_{1}\right)$ & -.036 & .020 & -164 & $\begin{array}{c}- \\
1.749\end{array}$ & .083 \\
\hline Prakerin's experience $\left(\mathrm{X}_{2}\right)$ & .005 & .011 & .043 & .459 & .647 \\
\hline Interests Work $\left(\mathrm{X}_{3}\right)$ & .166 & .177 & .087 & .940 & .349 \\
\hline $\begin{array}{ll}\text { Dependent variable }(\mathrm{Y}): \mathrm{W} \\
\text { t tabel } & : 1,9726 \\
R \text { Square } & : 0,30 \\
\text { Adjusted R Square } & : .005\end{array}$ & ig reac & & & & \\
\hline
\end{tabular}

Based on the above table, the resulting regression equation is as follows.

$\hat{Y}=5.557-0.036 \mathrm{X} 1+0.005 \mathrm{X} 2+0.166 \mathrm{X} 3+0.95$.

The regression equation can be interpreted that if the learning achievement of productive training (X1), prakerin (X2) experience, and work interest (X3) is 0 , the work readiness is 5,557. Learning achievement of productive training (X1) can explain the readiness of work equal to $-0,036$ or equal to $-3,6 \%$ with assumption 
other variables remains. Prakerin experience (X2) can explain the readiness of work of 0.005 or equal to $5 \%$ assuming other variables remain. Interest in work (X3) can explain the readiness of work of 0.166 or equal to $16.6 \%$ assuming other variables remain. The value of Adjusted R Square value of 0.005 means that the contribution of learning achievement of productive training (X1), prakerin (X2), and work interest (X3) to job readiness (Y) is 5\%. The remaining 95\% can be influenced by other variables such as work motivation, family social support, and social environment of the community

Table 3. Effect of Learning Achievement of Productive Training Eye, Prakerin Experience, and Job Interests on Partial Job Readiness

\begin{tabular}{lcccc}
\hline \multicolumn{1}{c}{ Variable Free } & $\mathbf{t}_{\text {tabel }}$ & $\mathbf{t}_{\text {hitung }}$ & $\mathbf{S i g}$ & Explanation \\
& & & $\cdot$ & \\
\hline Achievement Learning Eye & 1,9726 & -1.749 & .08 & $\mathrm{H}_{01}$ rejected \\
Productive Training $\left(\mathrm{X}_{1}\right)$ & & & 3 & \\
\hline Prakerin's experience $\left(\mathrm{X}_{2}\right)$ & 1,9726 & .459 & .64 & $\mathrm{H}_{02}$ rejected \\
& & & 7 & \\
\hline Interests Work $\left(\mathrm{X}_{3}\right)$ & 1,9726 & .940 & .34 & $\mathrm{H}_{03}$ rejected \\
& & & 9 & \\
\hline
\end{tabular}

Based on Table 3 it is known that the learning achievement of productive training (X1) has a tcount $-1,749$ and ttable of 1.9726, meaning that the value of $t$ count is smaller than ttable so that $\mathrm{H} 01$ which states there is a positive and significant influence between learning achievement of productive training readiness work rejected. Prakerin experience (X2) has a value of tcount 0.459 and ttable of 1.9726 , meaning that the value of $t$ count is smaller than the ttable so that H02 which states there is a positive and significant influence between prakerin experience of job readiness is rejected. Interest in work (X3) has a value of t9 0.940 and ttable of 1.9726 , meaning that the value of $t$ count is smaller than the ttable so that H03 which states there is a positive and significant influence between work interest on work readiness rejected.

\section{Discussion}

Description of variables of learning achievement of productive training is classified well, this can be proved by $98,80 \%$ of business class XII student of SMK Negeri 1 Kraksaan Probolinggo have value above KKM (minimum completeness criterion) value is spread between 80 until 89 with the percentage so that it can be concluded that the majority of students have mastered vocational theory well. Prakerin experience is classified well, it can be proved by $89.28 \%$ of students get final prakerin value above KKM, that is spread between 80 up to 97 with percentage vary on each item its value so it can be concluded that majority of prakerin participant have a good experience because the value they get is a pure value from the industrial side which in this case is an outsider who has monitored student activities so that without any element of doubt in objectively assessing.

Description of the student's work interest variable is classified well, it can be proved by the average score obtained by this variable is 4,077 , it means that in every 
revelation proposed the students answered strongly agree or agree that the students have been preparing to enter the work world, increase knowledge, after graduating from vocational school, students choose vocational schools because they are related to the world of work, always eager to follow the activities at school, want to be financially independent, and students agree that work is a way to be financially independent, grateful if after graduating have a job fixed and unemployed and students are very grateful for the initial salary they receive.

Description of work preparedness variable is classified well, this can be proved by the average score on this variable is 4,042 , it means that in every statement submitted the majority of students answered agree or strongly agree that prakerin process make students more mature emotionally, mature age to work, have sufficient knowledge to enter the work world, the knowledge gained in school is very useful to complete the task of industry, mastering many skills in the field, the skills possessed today make students more confident to enter the workplace, students can complete the whole the tasks given by teachers, schools, and industry parties well, and students feel the experience is good enough to stock enter the world of work.

The results showed that the learning achievement of productive training did not have a positive and significant effect to the readiness of the students in the XII class of business and management skill in SMK Negeri 1 Kraksaan Probolinggo. This can be seen from the value of $t$ count smaller than ttabel so that it can be concluded that there is no positive and significant influence between learning achievement of productive training to the readiness of student work.

Achievement learning eye productive training is a description of the ability of students in mastering the material and skills in the field that they intereted. According to Wena (1997: 27) the learning of productive training is more emphasized on the learning of vocational theory combined with industrial material that is emphasized in practice, while Kuncoro (1996: 4) states "Productive components contain study materials and lessons that equip professional work skills and attitudes according to the capabilities demanded by the world of work ".

Based on research conducted by Datadiwa \& Widodo (2015: 32) states that "Ideally after experiencing the learning process and obtain a good learning achievement, it will affect the readiness of students' work well and positively". Similarly, research conducted by Baiti \& Munadi (2014: 168) which explains that productive learning in vocational school as a learning that is focused on the ability of certain skills as a provision to enter the workforce. Similar results were also presented by Kurniati \& Subowo (2015: 412) in his research stated: "Academic achievement or knowledge is a factor that can affect one's work preparedness".

The results of this study are not in accordance with previous studies that have been done. The difference between the results of previous research with this research can be caused by the difference of school environment, the facilities of each school, and the background of each respondent in each different area so as to cause the learning achievement of productive education training does not have a significant positive effect on the readiness of the students' work. Another reason is that based on an open option provided by the researcher that, students who have high learning achievement or good grades report prefer to continue their studies to 
a higher level than work. This means that the interest to continue college in students is much greater than the interest to work.

For students of SMK the role of learning achievement productive training is very important because it is one indicator that can show the ability of students in mastering the material in the field being occupied. Mastery of good material will be useful for students when entering the workforce later because with good mastery of the material will be easier students in work and students will be better equipped to face the workplace. In addition, although the results of the study show that students in business and management class XII SMK Negeri 1 Kraksaan Probolinggo more interested to continue college but in the end they will still work and enter the world of work so that a good learning achievement in the eyes of productive training is very important to have my students SMK. The hope of this student achievement is the awareness of the students themselves not only because of the pressure or encouragement of teachers only, so that in the view of students learning is no longer a demand or compulsion but a necessity.

The result of the research shows that prakerin experience has positive but not significant effect on the readiness of XII class student in business and management skill in SMK Negeri 1 Kraksaan Probolinggo. This can be seen from the value of $t$ count smaller than ttable so that it can be concluded that there is no significant influence on student achievement on student readiness.

The success of students in undergoing prakerin process can be seen from the value of prayer in obtained by students from the DU / DI. Wena (1997: 24) states "The dual system education consists of a mixture of sub-systems of education in schools and sub-systems of education in the world of work/industry". While Yunus (2006: 147) states "The dual system model is basically a fusion of the market model and model of the school, in this case, the government acts as the watchdog of the market model, the system is called dual system because the implementation is done in two places, business world industry ". From the above statement simply prakerin or PSG (apprenticeship) is a learning activity that combines two aspects at once namely theoretical aspects in schools with real conditions on the business and industry

Based on the results of previous research by Handayani \& Setiayani (2015: 874) stating that in his research there is a positive and significant influence variable prakerin with work preparedness. The same results were also revealed by Lestari \& Siswanto (2015: 129) that there is a positive and significant influence between prakerin experience and students' readiness. In addition, research conducted by Baiti \& Munadi (2014: 178) states "The results revealed that there is a positive and significant influence between the practice experience on the readiness of vocational students". The result of other research on prakerin experience and work preparedness done by Muktiani (2014: 171) also resulted that prakerin variable positively influences to the readiness of work significantly.

The results of this study are not in line with previous studies. The occurrence of differences between the results of previous research with this research can be caused by differences in work culture characteristics in each DU / DI each region. A conducive working culture will affect the readiness of work with a positive but not conducive work culture until the unhealthy competition in the institution where 
students do prakerin will have a negative impact on the readiness of students work such as lack of work experience that students get when in prakerin.

Based on the results of the study, $92 \%$ of students do prakerin on government agencies and retail companies large scale / small. The place is a working world that has a clear and measurable structure, so it will not provide freedom for students in developing their thinking and creativity. Based on the experience of researchers when following the prakerin process while in SMK, basically although the industry receives prakerin participants well but with the prakerin participants the industry still do not want to damage the composition of work that has been applied before so that students who follow prakerin only allowed to conduct activities in accordance with the orders of the prakerin coordinator only, without any activities of innovation, exploration, and freedom in performing their duties. In the absence of orders, prakerin participants can not do the activity, meaning that students who follow the prakerin Vocational Practice is indeed doing work activities in the industry but only limited to the executive order only prakerin coordinator whose nature is only basic and non technical work.

Viewed from the aspect of the curriculum, about the length of prakerin implementation in SMK Negeri 1 Kraksaan Probolinggo is 3 months. The experience of being in the world of work for approximately 3 months cannot meet the needs of students to know widely about the world of work. Approximately 2 years of the learning process in school but only given the opportunity to practice within 3 months. If the vocational students are oriented to be ready for work then the combination of learning should be the same as the learning process in the world of work, because the longer the students carry out prakerin will be easier also for students later to adapt to the world of work.

However, prakerin implementation is important for students of SMK because of this prakerin makes the vocational different from another high school. Good mastery of matter without being balanced with adequate practice ability will be in vain. So that vocational students need this prakerin as a container to practice their knowledge and skills before entering the real workplace.

The result of the research shows that the interest of work has the positive but not significant effect on the readiness of the students of class XII in business and management skill in SMK Negeri 1 Kraksaan Probolinggo. This can be seen from the tcount value is smaller than ttable so it can be concluded that there is no significant effect on the interest of work on the readiness of students work.

Yunus (2006: 119) states that "Student interest will arise if the students already have a commitment". An interest in students can form a firm commitment. Because of the interest, students are not easily influenced by the environment, especially the environment that is less good for psychological students. Interests are the feeling of more interest that arises from within a person to a job that makes a person feel happy and eager to do all activities related to the world of work. Meanwhile, according to Djaali (2009: 121) "Interests are a sense of preferences and a sense of interest in a thing or activity, without any telling, interest is basically the acceptance of a relationship between yourself with something outside the self.

The results of this study are not in line with the results of research that has been done by Septiana et al (2016) which states that if a student has a high interest in work then it can be stated that students have good or high job readiness, but if a 
student has a working interest low then the conclusion of the students' work readiness is also low. The results of this study are also not in accordance with research conducted by Mu'ayati \& Margunani (2014: 334) states that "There is an influence between student work interests on job readiness".

The occurrence of differences between the results of previous research with this research can be caused by the state of interest in different students such as interest for work, interest for entrepreneurship and also interest to continue to college. Based on the open options that have been provided on the questionnaire the majority of students who answered no interest to work because students want to continue college to college. Not only the interest in the work of students who can be used as a picture that students who interest to work will be ready to enter the workforce because to be said to be ready to work students must have skills and knowledge that occupy. In the first indicator of the drive to prepare for work the students are still less prepared because based on open options, there are still students who call themselves minimal knowledge, experience and not old enough to work. This indicates that students have not met the first indicator in preparing to enter the workforce, sufficient experience, and knowledge that is in their field.

Nevertheless, it is important that there is interest in the students because basically, the vocational school is a vocation-oriented school graduate ready to work so that with the interest of work in students can facilitate the school in preparing its graduates into a competent workforce. the high achievement of students and the good work experience of students if the students do not have the interest to work then it is in vain.

\section{CONCLUSION \& SUGGESTIONS}

\section{Conclusion}

The results of this study indicate that: (1) Student learning achievement of productive student training in the good category, this can be proved by $98,80 \%$ of students have the average value of odd semester reporting academic year 2016/2017 spread among 80-89 with diverse percentages; (2) student prakerin experience in the good category, this can be proved by $89,28 \%$ students get prakerin pristine final value from party DU / DI spread among 80-97 with a various percentage (3) student's interest in good category or very interest, this can be proved by the average score of the questionnaire that is 4,077 , meaning that in every state the majority of students answered agree and strongly agree (4) Readiness work students are in a good category or ready to work, this can be proved by the average score the average questionnaire on the readiness statement is 4,042, meaning that in each statement respondents or students answered agree and strongly agree (5) the learning achievement of productive education and training have a negative and insignificant effect on the readiness of students' work; (6) prakerin experiences have a positive but insignificant impact on students' readiness; (7) work interest have the positive but not significant effect to students' readiness in SMK Negeri 1 Kraksaan Probolinggo. 


\section{Suggestion}

Based on the results of research, suggestions that can be given by researchers at SMK Negeri 1 Kraksaan Probolinggo namely; (1) for product education training teachers are expected to continue to maintain and improve their skills in teaching because based on findings, $92 \%$ of business management students have learning achievement above KKM, this is a very good result so it is necessary to be maintained; (2) for the prakerin responsible person on the basis of the findings, $84 \%$ of students who follow prakerin get good grades and spread among 78-97, this is not apart from the learning process in school that has been passed by students before implement prakerin, and the role of the person in charge prakerin in providing prakerin departure, it is necessary to be maintained by maintaining good relations with DUDI (3) for business management students in SMK Negeri 1 Kraksaan Probolinggo based on findings in this study students should continue to improve their skills and knowledge through learning because there are still $8 \%$ of students who have scores that do not reach KKM for productive training, and 16\% of students who get a prakerin final score below 75, since the evaluation is not enough only from the teacher but from each student (4) for future researchers should need to reproduce the reference jurn al or the book in conducting a review of other variables that can affect the readiness of SMK students such as work motivation and social support of the family, so the more enriched list of independent variables that can affect the readiness of vocational students and can provide accurate information for the reader so that the results of research done more useful.

\section{REFERENCES}

Baiti, A.A. \& Munadi, S. 2014. Influence of Practice Experience, Basic Vocational Learning Achievement and Parents Support to Vocational Students Readiness. Journal of Vocational Education, (Online), 4 (2): 164-179, (http://journal.uny.ac.id/index.php/jpv/article/view/2543), accessed on 29 November 2016. (Indonesian Origin).

Djaali, H. 2009. Educational Psychology (Tarmizi, Ed.). Jakarta: Earth Literacy. (Indonesian Origin).

Datadiwa, D. \& Widodo, J. 2015. Analysis of Factors Affecting Readiness of Work Students SMK Negeri 1 Warureja Year 2014. Economic Education Analysis Journal, (Online), $\quad 4 \quad$ (1): 31-37, $\quad$ (http: // journal.uny.ac.id/sju/index.php/eeaj/article/view/4679), accessed on November 29, 2016. (Indonesian Origin).

Handayani, U.S. \& Setiyani, R. 2016. The Effect of Academic Achievement of Productive Accounting Training, Industrial Work Practices, and Family Environment on Work Readiness of Grade XII Students of SMK Negeri 1 Kebumen Accounting Expertise Program of the academic year 2014/2015. Economic Education Analysis Journal, (Online), 4 (3): 864-875, 
(http://journal.unnes.ac.id/sju/index.php/eeaj/article/view/8528), accessed on the 29th November 2016. (Indonesian Origin).

Kuncoro, T. 1996. Vocational High School Curriculum Development Technology Related Business. Malang: Part of IKIP Malang Operation and Maintenance Facility Project. (Indonesian Origin).

Kurniati, U. \& Subowo. 2015. The Influence of Industrial Work Practices, Academic Achievement, and Work Motivation for Students Work Readiness Class XII SMK Negeri 1 Brebes Academic Year 2013/2014. Economic Education Analysis Journal, (Online), $4 \quad$ (2): 404-413, (http: // journal.unnes.ac.id/artikel_sju/eeaj/6772), accessed on 29 November 2016. (Asli Indonesia).

Mu'ayati, R. \& Margunani. 2014. The Influence of Industrial Work Practice (Prakerin), Proficiency of the Eye of Productive Training of Accounting and Student Interest in the Preparing for the Working World of SMK Students Accounting Program at SMK 1 Salatiga Academic Year 2013/2014. Economic Education Analysis Journal, (Online), 3 (2): 327-335. (http: // journal.unnes.ac.id/sju/index.php/eeaj/article/view/3934), accessed on November 29, 2016. (Indonesian Origin).

Muktiani, E.E. 2014. The Influence of Industrial Work Practices and Academic Achievement of the Eye of Productive Training of Accounting for Student Readiness of Class XI Accounting Expertise Program of SMK Nasional Pati Lesson Year 2012/2013. Economic Education Analysis Journal, (Online), 3 (1): 166-172, (http://journal.unnes.ac.id/sju/index.php/eeaj/article/view/4231), accessed on the 29th November 2016. (Indonesian Origin).

Septiana, E.N., Fathoni, A., \& Minarsih, M.M. 2016. The Influence of Internship, Interests and Orientation, Expertise Specialist on Student Readiness (Empirical Study at Department of Culinary Class XII SMKN 6 Semarang). Journal of Management, (Online), 2 (2), (http://jurnal.unpand.ac.id/index.php/MS/article/download/575/560), accessed on November 29, 2016. (Indonesian Origin).

Sugiyono. 2015. Statistics for Research. Bandung: Alfabeta. (Indonesian Origin).

Wena, M. 1997. Dual System Vocational Education. Malang: Part of IKIP Malang Operation and Maintenance Facility Project. (Indonesian Origin).

Tirtarahardja, U. \& Sulo, S.L.L. 2005. Introduction to Education. Revised Edition. Jakarta: PT Rineka Cipta. (Indonesian Origin).

Yunus, M. 2006. Vocational Education Partnership Policy: Concept, Application, and Policy Implementation Process (Setiyo Wahyudi D.Ng, Ed.). Malang: Surya Pena Gemilang and Kayutangan Library. (Indonesian Origin). 